\title{
The Gender Wage Gap Opens Long before Motherhood. Panel Evidence on Early Careers in Switzerland
} \author{
Centre LINES, University of Lausanne, 1005 Lausanne, Switzerland \\ *Corresponding author. Email: daniel.oesch@unil.ch; benita.combet@Imu.de \\ Submitted April 2018; revised January 2019; accepted February 2019
}

${ }^{1}$ Swiss National Centre of Competence in Research LIVES, University of Lausanne, ${ }^{2}$ Department of Sociology, LMU University of Munich, 80801 Munich, Germany and ${ }^{3}$ Life Course and Inequality Research

\section{Introduction}

Over the last few decades, women have made up ground with respect to men in key areas of social life, from educational enrolment to political representation. However, one area where progress is slow and the gender gap persistent are wages, with women still earning substantially less than men (OECD, 2012; Blau and Kahn, 2017). According to an influential argument in economics, the earnings trajectory of men and women diverges because of the division of labour within families, with fathers specializing in paid employment and mothers focussing on housekeeping and child-rearing (Becker, 1985;
Polachek, 2006). In anticipation of their future family roles, young men and women may choose different fields of study and take up work in different occupations. Following this argument, the gender wage gap persists not because of employer discrimination against women, but because of the differential investment of men and women into paid work and the household.

Our article tests the family roles argument by analyzing the wages of a birth cohort of childless young men and women up to the age of 30 . This allows us to compare the evolution of wages before the onset of gendered 
household specialization. If unequal wages are exclusively caused by differential investment into employment and child-rearing, we should not observe, for a given level of education, field of study and occupation, a genthe contrary, an unexplained gender wage gap among childless workers points to discriminatory wage-setting and suggests that young women continue to earn lower wages than young men despite comparable skills (OECD, 2012: p. 172).

Wage discrimination is not only detrimental to women, but should also be disadvantageous to discriminatory employers because they reward workers for characteristics that have no bearing on productivity. Accordingly, Gary Becker (1957) expected discrimination to be a transitory phenomenon in competitive labour markets as discriminatory employers would eventually be driven out of business (see Pager, 2016). We examine this argument and analyze the gender wage gap for one of the most competitive labour markets in Europe, Switzerland. In Switzerland, unemployment is low, work migration high, employment protection weak, there is no legal minimum wage and collective wage-bargaining covers less than half of the workforce (Murphy and Oesch, 2018). Following Becker's argument, it should be particularly hard to find wage discrimination in Switzerland.

Our paper makes three contributions. First, it provides a comprehensive test of the argument that, as titled by the

30 New York Times, 'the gender pay gap is largely because of motherhood' (13. 5. 2017). It does so by analyzing early careers with a unique panel dataset for Switzerland, called 'Transitions from Education to Employment' (TREE) which follows a Programme for International

35 Student Assessment (PISA) cohort of young people from the age of 15 up to the age of 30 ( 9 waves). Our analysis explicitly accounts for the anticipation of family formation by excluding the wage observations of individuals who have children in later waves and by controlling for school leavers' attitudes towards work and family.

Second, we use this cohort study to show how the earnings of young men and women are affected by three channels that partly overlap with different career stages: by initial educational credentials, the subsequent labourmarket behaviour and the anticipation of future family roles. We disentangle the influence of these three mechanisms by first matching men and women on a long list of pre-market characteristics such as social origin and education attainment. We then add control variables for their employment choices and family anticipation.

Third, we provide evidence for the robustness of our results by replicating our analysis with a second panel study, the Swiss graduate survey. This panel study contains the earnings of young men and women 1 and 5 years after they graduated from tertiary education. The two datasets provide us with detailed measures for school degrees, job characteristics, and value orientations. If women earn lower wages because their fields of study are less rewarding (Ochsenfeld, 2014) or their jobs require less effort (Becker, 1985: p. 52), our analysis will pick up these effects.

Our article first discusses the sources of the gender wage gap by contrasting the two arguments of gendered household division of labour and pay discrimination. It then presents the institutional context, data, and matching method of our analysis. The results section shows the wage trajectories of young men and women with both random- and fixed-effects models and presents the findings of a Blinder-Oaxaca decomposition analysis. The conclusion discusses the policy implications of a persistent gender wage gap.

\section{The Gender Wage Gap and the Household Division of Labour}

Traditionally, the gender wage gap has been explained by differences in human capital between men and women (Becker, 1985). Yet over the last decades, educational attainment between men and women has converged across the western world, and in a growing number of countries the gender gap in university completion has reversed from favouring men to favouring women (DiPrete and Buchmann, 2013: p. 32). The fact that gender differences in education-and in work experience (Goldin, 2014: p. 1093)—narrowed much more than the gender wage gap has been 'an embarrassment to the human capital interpretation of sexual earnings differentials' (Becker, 1985: p. 35) and called for an adaption of the theory.

The human capital explanation of the gender wage gap therefore shifted its focus to the household division of labour. The argument is that in anticipation of parenthood, men specialize in paid work and continue to invest in their job-specific skills, whereas women specialize in child care and choose family friendly jobs which demand less effort and less intensive training (Becker, 1985: p. 36). If young women expect more discontinuous work careers as a consequence of their future family responsibilities, they may choose fields of study and occupations that are less rewarding, but more easily compatible with childrearing (Blau and Kahn, 2017: p. 817). Once the children are born, mothers tend to spend more time out of the labour force, accumulate less work experience, have shorter 100 working hours, are less likely to get promoted and experience lower earnings growth over time (Gangl and Ziefle, 
2009: p. 355). In short, due to the gendered division of labour within the family, women may commit less time and energy to the labour market than men.

There is ample evidence for the negative effect of children less than non-mothers (e.g. Budig and England, 2001; Gangl and Ziefle, 2009; Oesch et al., 2017) and having children slows down wage growth for women, but not for men (e.g. Marini and Fan, 1997; Fuller, 2008). Consequently, 10 accounting for marriage and children reduces the gender wage gap (Aisenbrey and Brückner, 2008: p. 643).

Some scholars have interpreted these findings as providing evidence that the gender wage gap is solely rooted in joint household decisions. An influential proponent is Mincer, who writes in a book edited by Francine Blau and David Grusky that 'I go as far as to argue that this detrimental [household] division of labour is at the root of almost all the [gender] wage gap' (Polachek, 2006 [2004]: p. 27).

20 According to this view, the gender wage gap basically sums up to a gap between men, who invest in labour-market skills, and mothers, who invest in child-rearing skills. This argument has also gained political traction as it conveniently shifts the focus from employers to households and has been widely echoed by newspapers and think tanks. ${ }^{1}$

\section{The Wage Gap in Early-Careers as Crucial Test}

The implications of this argument are far from trivial. If the gender wage gap is better termed a family wage

gap, the political initiatives to subdue wage discrimination against women are bound to fail-simply because there is no discriminatory wage-setting by employers in the labour market. If there is any discrimination, it relates to the non-market domain and couples' decisions wo specializes in paid work and who takes on responsibility for domestic work.

The ideal test for this argument is to focus on earlycareer outcomes. Unmarried and childless young men and women are not burdened with childcare. Of course, they may anticipate parenthood and the gendered division of labour and invest different amounts of time and energy into their education and early work career. Yet to the extent that young men and women possess similar levels of education, work experience and on-the-job training and are employed in comparable occupations and industries, they should also earn the same wages. The family wage gap should be of no concern to them-and not send them on different earnings trajectories in their twenties.

What does the evidence on early careers tell us? For an unexplained wage gap for young women and men (ages 14-22) of 5 per cent (after controlling for race, human capital, family structure, aspiration, occupation, and industry). A larger wage gap is found for American men and women in their late 20s, reaching 10 (Goldin, 2014: p. 1096) to 14 per cent (Fortin, 2008: p. 906) in models controlling for human capital, education, labour market experience, cognitive and non-cognitive skills, personal characteristics as well as occupation and industry. Comparable studies on young adults in Europe show residual gender pay gaps that range between 5 and 10 per cent among university graduates in Germany (Ochsenfeld, 2014: p. 544; Francesconi and Parey, 2018: p. 74), 7 per cent in a cross-section for Switzerland (Bertschy et al., 2014: p. 297), 8 per cent in the British Household Panel (Manning and Swaffield, 2008: p. 986), and 10 per cent in administrative data for Finland (Napari, 2009: p. 140).

Clearly, the gender wage gap opens before family formation sets in. This leads to the question of what hides behind this 'unexplained' gender wage residual. A recent focus has been on psychological characteristics such as non-cognitive traits, the desire to compete or negotiation skills. Based on two American panel surveys, Fortin (2008) finds that although there is convergence in how important work is for young men and women, men still tend to be more ambitious and value money more than women. While this difference may account for one to two percentage points of the gender wage gap, the unexplained residual remains large (Fortin, 2008, see also Manning and Swaffield, 2008).

Men and women may have different attitudes towards work and family and these differences may, in turn, translate into different wages through negotiation skills. Evidence from both surveys and field experiments suggests that men are more likely to initiate salary negotiations (Babcock and Laschever, 2009). A large metaanalysis cautiously concludes that men tend to achieve better economic outcomes in negotiations than women, although these gender differences strongly depend on the context (Mazei et al., 2015). Moreover, negotiation outcomes may be endogenous to entrenched wage differentials: If women face discrimination in the labour market that reduces their salaries relative to men's, their expected outcome from wage negotiations will be lower than for men (Blau and Kahn, 2017: p. 843).

\section{Wage Discrimination Against Women}

In sociology, it is widely accepted that others factors than productivity affect earnings, notably power resources such as trade unions and collective bargaining as 100 
well as social norms (Jacobs and Steinberg, 1990). Of particular relevance for our study is the social norm that grants men priority on the labour market. Especially in conservative gender regimes such as in

5 Switzerland, men are encouraged to become breadwinners and women secondary earners. ${ }^{2}$ This social norm is shared by both employees and employers and thus likely to translate into higher reference wages for men than women (Lalive and Stutzer, 2010). Indeed, survey experiments systematically show that respondents attribute higher wages to men than women who possess identical skills and credentials-be it in the United States (Jasso and Webster, 1997), Germany (Auspurg, Hinz Sauer, 2017), or Switzerland (Jann, 2003).

These results raise the issue of gender discrimination, defined as unequal treatment of men and women on the sole basis of their gender (Pager and Shepherd, 2008: p. 182). In theory, a distinction is often made between tastebased discrimination - a dislike rooted in prejudice and stereotypes - and statistical discrimination where recruiters expect different groups to have different average productivity (Becker, 1957). In practice, the two types of discrimination may not be very different-because employers' productivity estimates are based more on beliefs and stereotypes than on statistical information about actual productivity (Tomaskovic-Devey and Skaggs, 1999: p. 424). For our definition of discrimination as unequal treatment on the basis of gender, it does not matter whether the underlying causes are stereotypes and/or statistical reasoning.

What matters more is that wage discrimination against women is not a merely academic topic. Most Western countries have legislation on equal pay-and this legislation leads to a multitude of grievances. The most telling example is the United Kingdom where there were no less (Gilbert, 2012: p. 138). Although only a minority of cases is settled in favour of the female claimants-Deakin et al. (2015: p. 385) quote a proportion of 20 per cent for 1976 1998-the sheer numbers of claims suggest that wage dis-

40 crimination against women is far from anecdotal. While the legal hurdles for equal pay claims are much higher in Switzerland (Lempen and Voloder, 2017), nothing suggests that the British labour market is an outlier. In 2010, Britain's raw gender pay gap was 18 per cent and thus close to the OECD average of 16 per cent-and lower than Switzerland's gap of 20 per cent (OECD, 2012: p. 167).

\section{Channels Through Which Family Roles Affect Wages}

Our goal is to analyze whether the gender wage gap is labour-market skills and women in child-rearing skillsor whether other mechanisms such as discrimination also play a role. We therefore need to account for the different channels through which family roles, and their anticipation, may affect the wages of young men and women. We distinguish three mechanisms.

A first channel relates to individuals' investment into education and skills before they enter the labour market. The earnings potential of young men and women may vary because of their social origin, intellectual ability, level of education and, importantly, field of study. Field of study is a central indicator of pre-market segregation. Women may cluster in different fields because of gendered socialization (Polavieja and Platt, 2014) or because they anticipate part-time work and thus choose fields that lead to family friendly (and low-paid) occupations (Ochsenfeld, 2014: p. 537).

While this first mechanism tells us whether men and women enter the labour market with different skills and credentials, a second channel relates to the subsequent labour-market choices made by young adults. Gender segregation in the labour market may lead young women to take up employment in less rewarding occupations and industries than young men (England, Allison and Wu, 2007; Murphy and Oesch, 2016). If young women anticipate career breaks, they may invest less time in acquiring job-specific skills (Polavieja, 2008) and benefit less from employers' on-the-job training (Evertsson, 2004). In addition, they may gain less work experience than men, which is particularly relevant because interruptions in the early career are costly in terms of future earnings (Gangl and Ziefle, 2009; Bertrand, Goldin and Katz, 2010).

A third channel relates to family formation. Although we exclude observations of respondents 3 years prior to having children, parental roles may be anticipated. If founding a family is a priority for many young women and making a career a priority for many young men, this may lead to differences in labourmarket behaviour that are unobserved-but which should show in respondents' attitudes towards work, family, and partnership when they enter the job market. Likewise, getting married may launch young men and women on different wage trajectories if marriage is interpreted by employers as a signal that their female employees will soon depart on maternity leave. ${ }^{3}$

Our analytical strategy is to systematically account for these influences of family formation on wages. We account for the first mechanism of pre-market skills and credentials by matching young men and women for their 100 ability, level, and field of education before they begin to work. We account for the second mechanism of 
employment segregation by additionally controlling for differences in labour-market behaviour such as occupation and industry, work experience and job-related human capital. We then account for the third mechan5 ism of family formation by excluding from our analysis the wage observations of individuals 3 years before they have children and by additionally controlling for marriage and respondents' value orientations towards work, family, and partnership prior to labour market entry.

If our data still show a substantial gender wage gap after these three channels have been accounted for, we need to conclude that this gap cannot be solely attributed to different family roles and their anticipation.

\section{Institutional Context}

15 We analyze the gender wage gap in early careers between men and women born in the mid-1980s. We do so for Switzerland, a country that combines a liberal labour market with a conservative gender regime. While the Swiss labour market shares common features with

20 Austria and Germany such as the importance of vocational education, the close link between education and employment as well as collective bargaining set at the industry level, the institutions governing the employment relations are substantially more market-liberal.

25 Employment protection is weak, coverage with collective bargaining low (below 50 per cent) and there is no legal minimum wage (Murphy and Oesch, 2018). The combination of market-liberal institutions, low levels of unemployment and strong work migration results in a very competitive labour market.

In terms of its gender regime, Switzerland clearly belongs to the group of conservative countries. At the national level, female suffrage was only introduced in 1971 and a gender-egalitarian marriage law brought into practice as late as 1988 . In the family policy index developed by Mandel and Semyonov (2006: p. 1923), Switzerland is at the bottom of the ranking due to its gender-conservative welfare state, not far behind Germany and the United States.

\section{Data}

Our analysis uses the first cohort of a nationally representative dataset for Switzerland called 'Transitions from Education to Employment' (TREE) (Gomensoro and Meyer, 2017). This longitudinal survey follows a youth cohort that participated in the PISA in 2000 when students were in their last year of compulsory schooling and thus around 16 years old. Individuals were surveyed each subsequent year until the age of 23 (until wave 7).
Wave 8 was conducted 3 years later (at the age of around 26) and wave 9 four years later (in 2014 when respondents were around 30).

Using the TREE dataset has several advantages. It is a cohort study that contains detailed information about the educational pathways and job characteristics. In addition, it is based on the PISA study in which pupils take a standardized test in reading literacy, providing us with information on respondents' reading skills and hence with a proxy for their general intellectual ability (Duckworth, Quinn and Tsukayama, 2012).

The initial baseline sample of the first wave of TREE consisted of 5,528 respondents. Over nine waves, attrition reduced the number to 3,142 respondents. As we are interested in individuals' behaviour in the labour market and thus need people to earn wages, we can only use 25 per cent of all observations (3,154 individuals and 6,875 observations). We determine the year of labour-market entry, and thus the first relevant job, based on the information that respondents had finished their full-time education and worked at least 2 days full-time in their main job as wage-earners. This leaves us with 3,043 individuals and 6,676 observations. We further account for the possibility that men and women anticipate family formation by restricting our analytical sample to those wage observations that were measured at least 3 years before the respondents had their first child $(-14$ per cent of all observations). Limiting our analytical sample to those observations without missing values on all of our control variables leaves us with an analytical sample of 1,862 persons and 3,635 person-years. ${ }^{4}$

A drawback of the cohort design is that respondents with tertiary education enter the labour market later and therefore contribute fewer wage observations to the analysis. This problem is heightened in TREE because the time lags between waves increase after respondents reach their mid-twenties. We therefore provide a robustness check by resorting to a second longtiudinal survey, the Swiss Graduate Survey. This cohort study only includes individuals who finished higher education in 2008 and who were surveyed 1 and 5 years after the end of their studies (in 2009 and 2013, respectively).

The Graduate Survey covers about the same time period in which TREE respondents finished their tertiary education. To make the two datasets as comparable as possible, we restrict our analytical sample of the Graduate Survey to individuals who are in the same birth cohort as the individuals in TREE. Whenever possible, we use the same variables and operationalized them in the same way as in TREE. The two waves of the Graduate Survey provide us with complete observations for the wages of 818-persons and 1,136, person-years 


\section{Measures and Matching Method}

Our dependent variable is the natural logarithm of respondents' gross monthly wage in Swiss Francs (CHF), standardized for a full-time job (40hours per 5 week) and adjusted for inflation. ${ }^{5}$ We exclude potential outliers by dropping monthly wages that are implausibly low (below 2,000 CHF) or high (above 20,000 CHF) for a full-time job in people's twenties.

The main challenge of our analysis is to compare the wages of men and women who are as similar as possible in terms of intellectual ability, human capital, and labour market behaviour. Our solution is to match men and women based on their socio-demographic and educational credentials before they enter the labour market. We use the matching method of entropy balancing (Hainmueller, 2012) which reweights the treatment and control group by assigning scalar weights to each sample unit so that the two groups match exactly on the specified moments of a set of covariates. ${ }^{6}$

We account for the first channel by matching men to women on the basis of their socio-demographic characteristics: age in months, place of birth in or outside of Switzerland, years of residency in Switzerland, family structure, respondents' social origin as measured with ISEI of both parents, and cultural capital. ${ }^{7}$ We then match men to women based on their educational ability by using the plausible PISA reading literacy scores, the school track attended in 9th grade as well as the number, type and field of the educational certificates achieved before entering the labour market. ${ }^{8}$ The final matching weight was calculated by simultaneously including all the variables used in the previous weights. Supplementary Table W.1 shows that our matched groups of men and women look very much alike.

While we account for the first channel by using a matching method, we use a regression approach to add further variables in later waves that relate to the two subsequent channels. The second channel relates to the labour market where we control for further educational certificates, previous work experience before they entered the labour market (such as work experience in student jobs in months) and the number of jobs held so far (with an additional squared term as many job switches may send a negative signal). We determine the characteristics of the job with a large selection of measures, notably occupation (10 ISCO groups) and industry (19 sectors). ${ }^{9}$

We use three indices on self-reported job characteristics to account for Becker's assumption that women choose employment that is less strenuous and demandfortable temperatures, insufficient set-up of the

workplace), (ii) variety of tasks (possibility to learn new things, diversified tasks, skills can be applied fully); (iii) autonomy (influence about job tasks, possibility to choose solutions, possibility to work independently).

The third channel relates to the anticipation of family formation. We control for marriage (and an interaction between marriage and gender) as a potential signal to employers that the respondent may soon have children. Moreover, we account for respondents' attitudes towards work, partnership, and family by using three indices developed by Watermann (2000). These attitudes are measured before individuals enter the labour market (as an average over the waves preceding labour market entry). Although it is not uncommon to include attitudes in wage equations (see Fortin, 2008: pp. 885-886, Manning and Swaffield, 2008: p. 1014), they should only be relevant for earnings if they translate into concrete behaviour: into educational choices and labour market behaviour. Supplementary Table W.2 provides the descriptive statistics for all the variables.

\section{Analytical Strategy}

In our longitudinal data, wage observations are measured repeatedly for the same individuals. We account for this nested data structure and the non-independence of wage observations over time by estimating a random-effects model. We use the years of experience as time variable and the interaction of experience with sex in order to examine whether wage growth differs between the sexes.

Fixed-effects models would be preferable in order to limit unobserved heterogeneity. Yet since sex does not change over time, it is impossible to estimate such a within-effect. Still, we run fixed-effects models with interactions between sex and all independent variables to allow for the possibility that certain characteristics lead to higher wage returns for one sex than the other. Finally, we use a 2-fold Blinder-Oaxaca decomposition with coefficients based on a pooled regression over both groups (e.g. Oaxaca, 1973; Jann, 2008) in order to assess how much of the gender wage gap can be attributed to different skills and jobs-and how much is due to other unobserved sources. In order to base the decomposition on the largest number of wage observation possible, we use for each individual the first wage observation in their first year on the labour market. All 95 our analyses are weighted with the survey weights. ${ }^{10}$

\section{Results on the Gender Wage Gap}

Figure 1 presents the mean earnings of men and women in their early career over different waves and thus for 

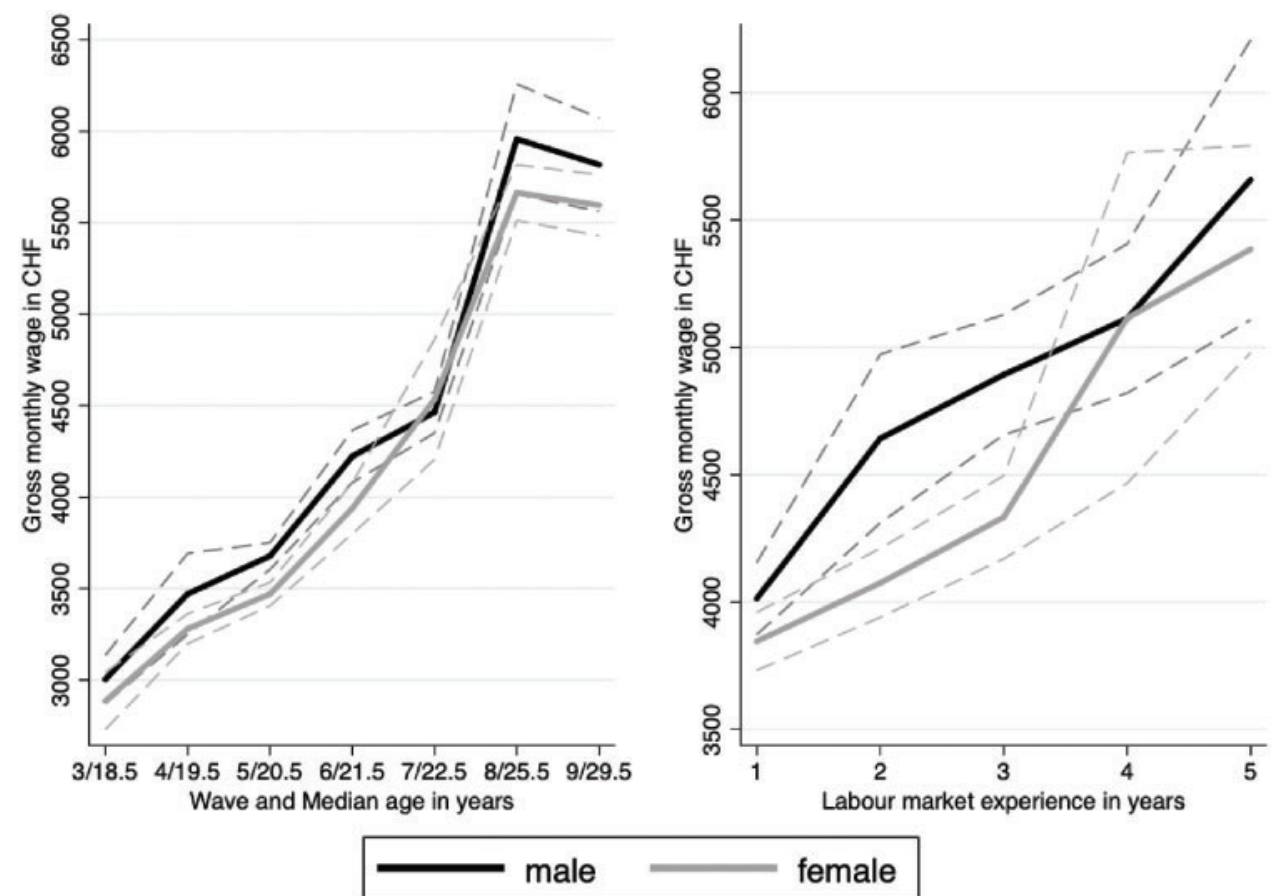

Figure 1. Mean earnings of men and women over the early career (with 95 per cent confidence intervals)

different ages (left-hand panel) as well as for different durations of work experience (right-hand panel). In the left-hand panel, we see that except for the entry age of 18.5 years, men earn more than women for all ages.

5 While the difference is sizeable between 19.5 and 21.5 years, it is small for the latter ages and not statistically significant. However, the individuals in our cohort vary in their years of education and do not enter the labour market at the same age. The left-hand panel thus does not properly distinguish between wage growth due to experience and wage growth due to the later entry in the labour market of individuals with higher education.

Therefore, we examine wage growth over the first 5 years of labour market experience in the right-hand panel. We censor work experience after 5 years to avoid a sample selection bias because few individuals in our sample have more work experience than 5 years-and they tend to be a selected group of early school leavers with lower educational degrees. Again, we find men to have consistently higher wages than women from the start of their career. The difference widens after 2 years of work experience and becomes statistically significant, but decreases again after 4 years.

As these descriptive analyses compare men and women who enter the labour market at different ages, with different educational degrees and different amounts of work experience, we need to analyze the wage gap in a multivariate setting. Table 1 shows the key coefficients of a random intercept model that matches men to women based on their socio-demographic characteristics and educational attainment as explained above (for all coefficients, see Supplementary Table W.3).

The baseline model 0 simply presents the estimates from the random-effects model without any matching or independent variables. It shows a raw wage gap of 5.4 per cent in favour of men. When introducing work experience as a measurement of time, we find a gender wage gap of 4.7 per cent in favour of men. If we match the male sample to the female sample according to their social origin in model 1.1 and their intellectual ability in model 1.2, the wage gap in favour of men increases to 7.2 per cent (model 1.1) and 8.8 per cent (model 1.2) respectively because young women tend to have higher cultural capital and better reading abilities. Matching on the educational certificates before they enter the labour market leaves the gender wage gap at 8.8 per cent (model 1.3) as women have on average higher educational credentials than men. However, if we account for the fields of study (or fields of vocational training), the wage gap drops to 4.5 per cent (model 1.4). This may be due because men choose more rewarding fields of study-or because male-dominated occupations are 


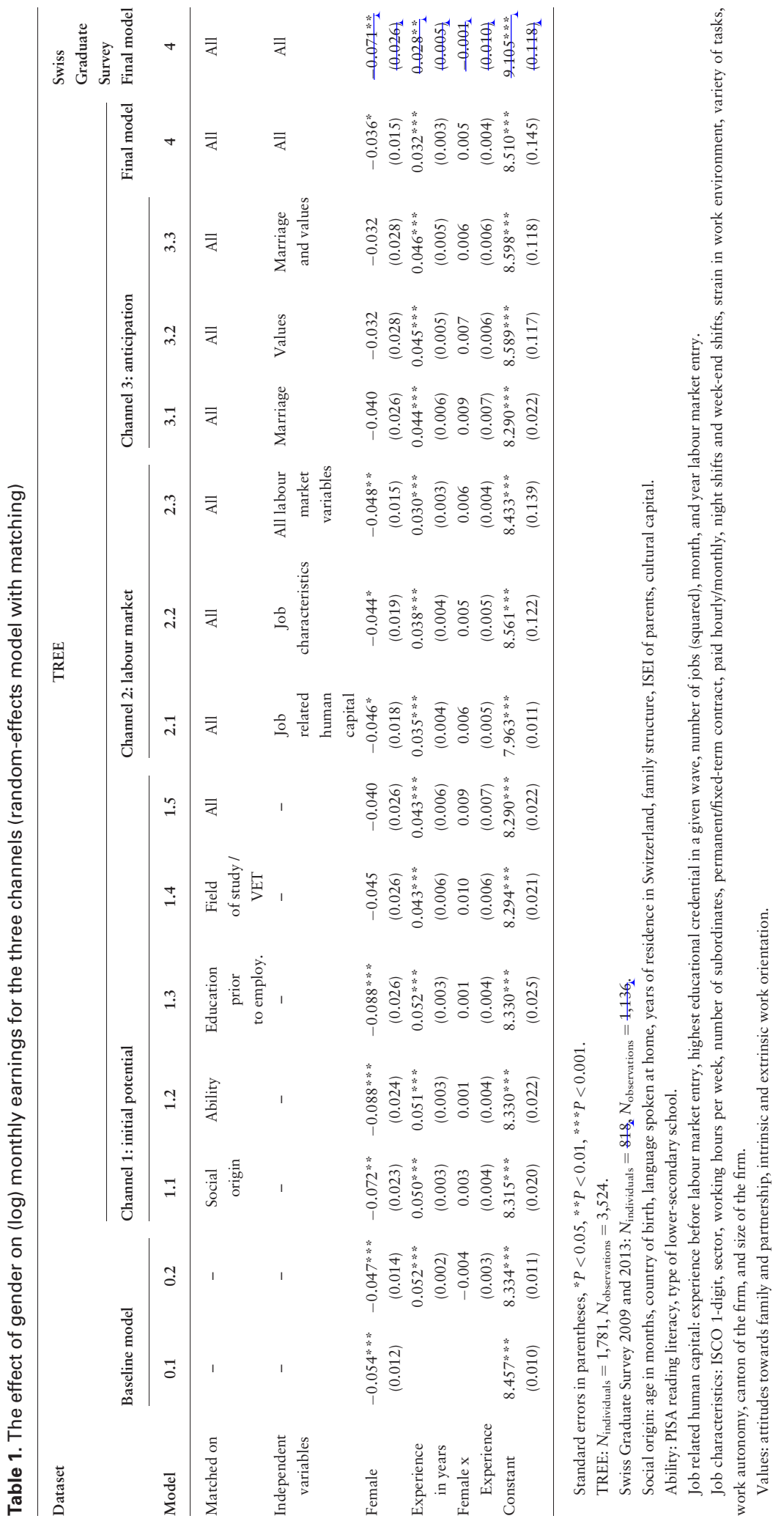


better paid (Murphy and Oesch, 2016). If we finally match the two sexes on all the 15 variables assessed before they enter the labour market, we find an unexplained wage gap of 4 per cent.

We account for the second channel by adding variables that measure job-related human capital. The wage gap amounts to 4.6 per cent (model 2.1). When including the characteristics of the current job (but removing job-related human capital), the gender wage gap remains basically unchanged at 4.4 per cent (model 2.2). Clearly, the demands and strains of a job do not explain why young men earn higher wages than young women. When including all the variables related to models 1 (education) and 2 (labour market), the gender wage gap is 4.8 per cent (model 2.3). This complete model accounts for all the (observed) variables directly related to work productivity—education, skills, and job characteristics-and thus probably corresponds to the model that would be used for the determination of equal pay between the sexes.

We account for the third channel by including variables that directly relate to the anticipation of parenthood such as marriage (interacted with gender) and attitudes towards work and the family. When interpreting these models, please note that equal pay commissions would be unlikely to consider values and civil status as legitimate determinants of wages. When accounting for marriage, we find a gender wage gap of 4.0 per cent (model 3.1). If we add values towards work, family and partnerin favour of men reduces to 3.2 per cent (model 3.2). The joint information on marriage and values also leaves us with a gap of 3.2 per cent (model 3.3). Finally, if we add all the variables of channels 1-3 in the same model, we find a gender wage gap of 3.6 per cent (model 4).

In terms of wage growth, our models show that each additional year of work experience is rewarded, all else equal, with an increase of about 3 per cent. The interaction effect of experience with gender is very small and not statistically significant. This suggests that wages evolve in parallel for men and women over the first few years of work experience.

\section{Robustness Tests}

Given the statistical controversy over the question of the gender wage gap (Blau and Kahn, 2017: p. 832), we run several sensitivity tests to see whether our results are robust (see Table A1 in the appendix). When estimating our model without outliers in wages, large matching weights, or influential observations, the wage gap gets weights reduces the wage gap. However, the results remain basically unchanged. If we further use different matching weights-weights in which women are balanced on men's characteristics (rather than men on women's characteristics) - the gender wage gap in model 4 increases to 6.4 per cent. This suggests that the wage gaps reported in Table 1 of between 3.6 (model 4) and 4.8 per cent (model 2.3) may be lower-level estimates.

In a next step, we analyze the earnings of young men and women with a different dataset, the Swiss Graduate Survey that followed school leavers 1 and 5 years after they had obtained a degree in higher education. By replicating our analysis for the same birth cohort, but a dataset that only includes people with tertiary education, we take into account that these individuals contribute fewer wage observations to TREE because they enter the labour market in later waves. While TREE provides us with a richer set of controls, the Graduate survey reduces heterogeneity between men and women by covering one single educational and birth cohort: individuals of the same age who had obtained a tertiary degree in the same year.

We estimate again a random-effects model where we match men and women on initial socio-demographic characteristics and intellectual potential (notably final grades) and then add control variables for the type and field of education as well as job characteristics. The results for the Graduate survey show a coefficient of 7.1. per cent in favour of men (see last column of Table 1). The gender wage gap among graduates from higher education thus resembles the 4-5 per cent obtained for the general youth population found with TREE.

With the exception of work experience which we interacted with gender, our random-effects models assume that men and women are rewarded identically for all their characteristics (such as a given education or occupation). We thus run separate fixed-effects models for gender to account for (time-constant) unobserved heterogeneity among men and women. We do so by including interaction terms between gender and all timevarying covariates. These results also suggest that the initial years of work experience lead to comparable wage returns for men and women (see Table A2 in the appendix). While men have higher wages than women from the onset of their career, the evolution of wages does not seem to differ over the first few years of work experience.

\section{Decomposition of the Gender Wage Gap}

In a last analysis, we turn to the Blinder-Oaxaca decomposition method and distinguish the proportion of the 100 


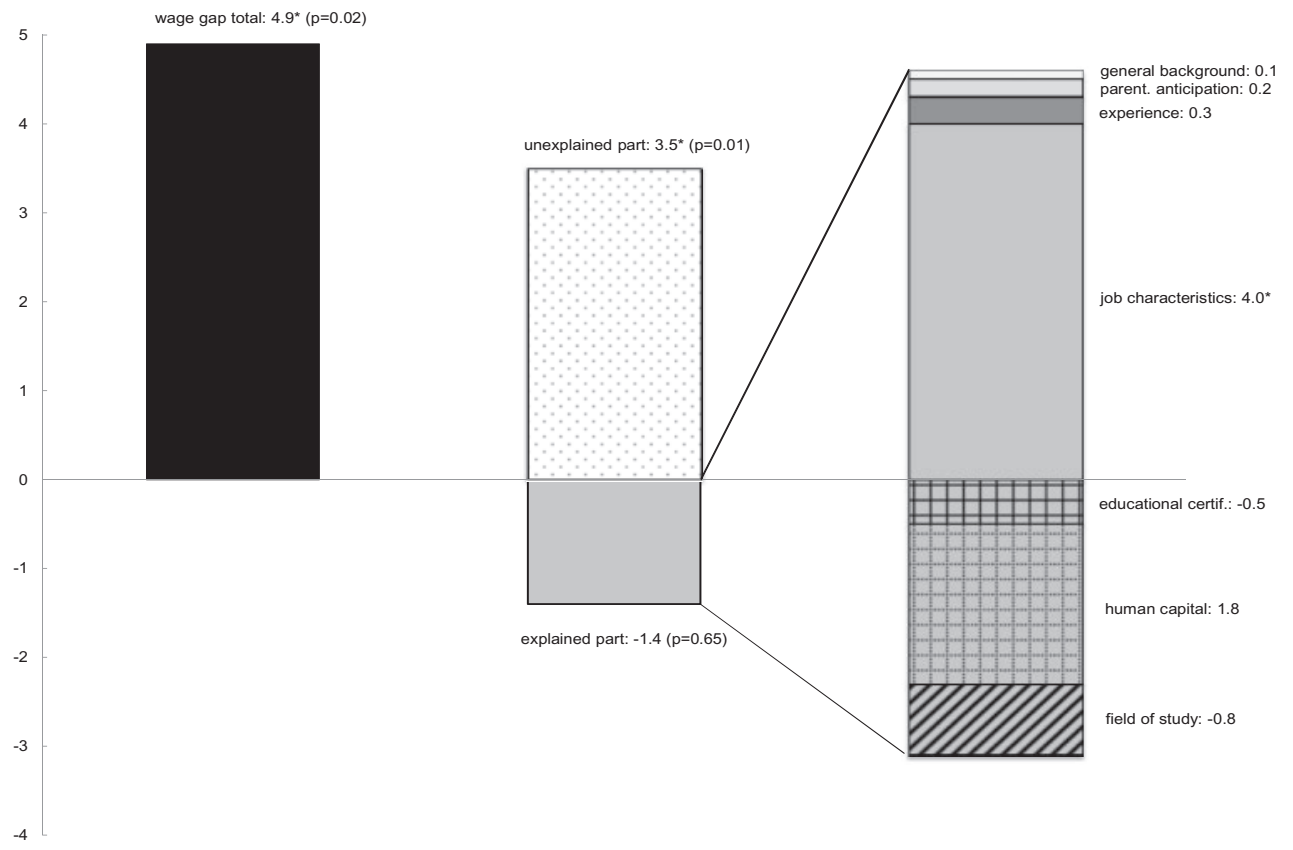

Figure 2. Blinder-Oaxaca decomposition of the gender wage gap (in percentage points)

gender wage gap that is attributable to the unequal endowment with productive characteristics between the sexes (the explained part of the gender wage gap) and the proportion that is due to men getting higher rewards

5 for the same productive characteristics (the unexplained part of the gender wage gap) (see Figure 2 and Supplementary Table W.4). For this analysis, we added the measures on which we matched men and women as independent variables in order to be able to quantify their contribution to the gender wage gap. For each individual, wages correspond to the first year of labour market experience.

Consistent with most of the random-effects models shown in Table 1 above, we find a gender wage gap of 4.9 per cent. The explained part is small $(-1.4$ percentage points). The only observable attribute that makes a significant difference are job characteristics: Young men work in jobs that are more rewarding than jobs held by women. All the other attributes turn out to be not statistically significant, although they suggest that young women should earn higher wages based on obtaining more human capital after labour market entry. However, the main result of Table 1 is that men and women born in the 1980s differ little in terms of human capital and labour market behaviour before they have children. This leaves us puzzling over the reasons behind the gender wage gap.

\section{Conclusion}

This article examined the argument that men and women's wage trajectories do not diverge prior to family formation. For this reason, we analyzed the wages of a birth cohort of young men and women over the first years of their career, before families are formed and partners specialize in either care or paid work. Our argument is that if unequal wages are exclusively caused by differential investment into employment and child-rearing, we should not observe, for a given skill-set and job, a gender wage gap before men and women have children.

Our evidence does not support the idea that the gender wage gap is solely explained by family formation. Our two panel datasets show that the gender wage gap already exists at the start of the career-and neither educational attainment nor labour market choices explain this disparity. We match the two sexes on their initial productive potential, we control for multiple differences in job characteristics and we even account for the presence of children, marriage and attitudes towards work and family-three features that equal pay commissions would certainly deem inadmissible. Whatever we do, we still find a gender wage gap.

At the bottom line, when using two different panel datasets of young workers in Switzerland, we find a residual wage gap of 3-6 per cent in favour of men. 
Translated into annual wages, this means that young women lose out on half a monthly wage each year in comparison to young men with the same productive characteristics. This result is consistent with the findings from other

5 European studies that report net wage penalties for young women of 5-10 per cent (Francesconi and Parey) or 6 per cent in Germany (Ochsenfeld, 2014), 7 per cent in Switzerland (Bertschy et al., 2014, Korber 2019: 113), 8 per cent in Britain (Manning and Swaffield, 2008), and 10 per cent in Finland (Napari, 2009). Our findings suggest that the gender wage gap remains constant over the first few years of careers as wages evolve in parallel for young men and women.

Clearly, the household division of labour does not 2006: p. 27) and the gender wage gap cannot be reduced to a family wage gap between men and mothers. Of course, the gendered division of labour in households with children strongly penalizes mothers' careers and wages - the evidence is clear for the United States (Budig and England, 2001), Western Europe (Gangl and Ziefle, 2009) as well as for Switzerland (Oesch et al., 2017). However, this is only part of the story. Our data suggest that young women earn lower wages than young men having comparable skills and working in comparable jobs long before they have children.

In the social sciences, scholars have become increasingly cautious in inferring discrimination from observational data. An unexplained wage gap of 3-6 per cent per se does not provide conclusive evidence for discrimination. However, to the extent that our two cohort studies provide us with homogenous samples and detailed measures of intellectual capacity, educational credentials, and labour market characteristics, we are hard pressed to find another plausible explanation. In this context, the US Supreme Court had ruled in 1977 that 'where gross statistical disparities can be shown, they alone may in a proper case constitute prima facie proof of a pattern or practice of discrimination' (Meier, 1986: p. 271).

Without an experimental design or firm-level data, we refrain from making such a strong statement. It should, however, be noted that the unexplained wage gap may not only overstate the extent of discrimination (if men have higher unmeasured productivity). It may also understate its extent if women have better unmeasured characteristics such as social skills or if an explanatory variable such as work experience, executive status or type of occupation have themselves been affected by discrimination (Blau and Kahn, 2017: p. 832).

Gary Becker (1957) made the famous prediction that discriminatory employers would eventually be priced out of the market in competitive labour markets. Over the period of our study, the Swiss labour market has been close to full employment and remains much less regulated in terms of labour law and collective bargaining than its neighbours Austria, Germany, France, or Italy. Yet although Switzerland has one of Europe's most competitive labour markets, we still find an unexplained gender wage gap of 36 per cent. The expectation that market forces will gradually eliminate the unequal treatment of men and women therefore seems overly optimistic. The invisible hand of the market has not done the job so far. It may now be time to rely more strongly on the visible hand of equal pay policies.

\section{Notes}

1 For the United Kingdom, see the Telegraph 'The gender pay gap is about motherhood. Everything else is just noise', Zoe Strimpel, 7. 4. 2017. For the US, see $V O X$ 'A stunning chart shows the true cause of the gender wage gap: the gender wage gap is really a child care penalty', Sara Kliff, 19. 2. 2018. For Switzerland see: Avenir Suisse 'Gleichstellung, warum der Arbeitsmarkt nicht versagt' [Equal gender rights, why the labour market does not fail], November 2015.

2 Note that this arrangement was enshrined in Switzerland's marriage law until 1988, giving husbands the status as legal head of family from whom wives needed the consent in order to take on paid employment.

3 Note that in Switzerland over 75 per cent of children are born to married couples in the 2010s (Swiss Federal Office of Statistics).

4 We are able to impute some missing data by assigning the value of the precedent year to a missing value if the information in the waves before and after a missing data point indicates no change. Additional analyses show that our results remain unchanged if we omit some of the control variables with many missing observations and analyze the models with a larger sample.

5 Wages and working hours are self-reported. Respondents could either specify the gross wage (76.3 per cent) or net wage (24.6 per cent). Further, they were asked whether they earn a monthly $(89.3$ per cent) or an hourly (10.7 per cent) wage. Additional wage components like a 13th monthly wage were included. The working hours are actual working hours and therefore include over-time work.

6 This method has the advantage that it prevents pos- 100 sible misspecifications of the propensity score model which could increase the bias on observed 更 
variables post-matching (see Hainmueller, 2012; Diamond and Sekhon, 2013). Our matching is done for individuals in the final sample. For all the different matching weights produced, all covariates are balanced on the third order of moment.

7 Cultural capital was measured as an index combining the frequency with which parents visited museums, theaters, and classical concerts with their children.

8 Educational certificates are differentiated into 11 categories. For the initial matching, we use four variables on educational certificate: the first and second educational certificate at the upper secondary level as well as the first and second certificate at the tertiary level. We use a 14-category variable to describe the field of education of the first and second educational certificate at the upper secondary and a 10 -category variable for the tertiary level. In the matching procedure, we also consider the number of certificates respondents achieved before entering the labour market.

9 Additionally, we control for the canton of the firm, size of the firm, working hours per week, number of subordinates, permanent or fixed-term contract, night shifts and week-end shifts, the way the salary is reported (hourly/monthly) and the month and year they entered the labour market.

10 The Stata syntax of the analysis is available at the GESIS datorium: https://datorium.gesis.org

\section{Supplementary Data}

Supplementary data are available at ESR online.

\section{Acknowledgements}

This research was supported by the Swiss National Centre of Competence in Research 'LIVES' on Overcoming Vulnerability:

35 Life course perspectives, financed by the Swiss National Science Foundation (grant number: 51NF40-160590). For their comments, we are grateful to the seminar participants in Milano (ECSR), New York (RC28), Venice (Rational Choice) and Zurich (TREE) as well as to the TREE team of the University of Berne and our colleagues Rudy Farys, Mailys Korber and Patrick McDonald. We also benefitted greatly from the comments made by the three anonymous reviewers and the associate editor Marie Evertsson.

\section{References}

Aisenbrey, S. and Brückner, H. (2008). Occupational aspirations and the gender gap in wages. European Sociological Review, 24, 633-649.
Auspurg, K., Hinz, T. and Sauer, C. (2017). Why should women get less? Evidence on the gender pay gap from multifactorial survey experiments. American Sociological Review, 82, 179-210.

Babcock, L. and Laschever, S. (2009). Women Don't Ask: Negotiation and the Gender Divide. Princeton: Princeton University Press.

Becker, G. S. (1957). The Economics of Discrimination. Chicago: University of Chicago Press.

Becker, G. S. (1985). Human capital, effort, and the sexual division of labour. Journal of Labour Economics, 3, 33-58.

Bertrand, M., Goldin, C. and Katz, L. F. (2010). Dynamics of the gender gap for young professionals in the financial and corporate sectors. American Economic Journal: Applied Economics, 2, 228-255.

Bertschy, K. et al. (2014). Gender wage gap at career entry. A quantitative analysis for Switzerland. Swiss Journal of Sociology, 40, 279-305.

Blau, F. D. and Kahn, L. M. (2017). The gender wage gap: extent, trends, and explanations. Journal of Economic Literature, 55, 789-865.

Budig, M. and England, P. (2001). The wage penalty for motherhood. American Sociological Review, 66, 204-225.

Deakin, S. et al. (2015). Are litigation and collective bargaining complements or substitutes for achieving gender equality? A study of the British Equal Pay Act. Cambridge Journal of Economics, 39, 381-403.

Diamond, A. and Sekhon, J. S. (2013). Genetic matching for estimating causal effects: a general multivariate matching method for achieving balance in observational studies. Review of Economics and Statistics, 95, 932-945.

DiPrete, T. and Buchmann, C. (2013) The Rise of Women: The Growing Gender Gap in Education and What it Means for American Schools. New York: Russell Sage Foundation.

Duckworth, A. L., Quinn, P. D. and Tsukayama, E. (2012). What "No Child Left Behind" leaves behind: the roles of IQ and self-control in predicting standardized achievement test scores and report card grades. Journal of Educational Psychology, 104, 439-451.

England, P., Allison, P. and Wu, Y. (2007). Does bad pay cause occupations to feminize, does feminization reduce pay, and how can we tell with longitudinal data? Social Science Research, 36, 1237-1256.

Evertsson, M. (2004). Formal on-the-job training: a gender-typed experience and wage-related advantage? European Sociological Review, 20, 79-94.

Fortin, N. (2008). The gender wage gap among young adults in the United States: the importance of money versus people. The Journal of Human Resources, 43, 884-918.

Francesconi, M. and Parey, M. (2018). Early gender gaps among university graduates. European Economic Review, 109, 63-82.

Fuller, S. (2008). Job mobility and wage trajectories for men and women in the United States. American Sociological Review, 73, 158-183.

Gangl, M. and Ziefle, A. (2009). Motherhood, labour force behavior, and women's careers: an empirical assessment of the wage penalty for motherhood in Britain, Germany, and the United Sates. Demography, 46, 341-369. 
Gilbert, K. (2012). Promises and practices: job evaluation and equal pay forty years on! Industrial Relations Journal, 43, 137-151.

Goldin, C. (2014). A grand gender convergence: its last chapter. American Economic Review, 104, 1-30.

5 Gomensoro, A. and Meyer, T. (2017). TREE (Transitions from Education to Employment): a Swiss multi-cohort survey. Longitudinal and Life Course Studies, 8, 209-224.

Hainmueller, J. (2012). Entropy balancing for causal effects. A multivariate reweighting method to produce balanced samples in observational studies. Political Analysis, 20, 25-46.

Jacobs, J. and Steinberg, R. (1990). Compensating differentials and the male-female wage gap: evidence from the New York State Comparable Worth Study. Social Forces, 69, 439-468.

Jann, B. (2003). Lohngerechtigkeit und Geschlechterdiskriminierung.

15 Experimentelle Evidenz. ETH Zurich, available from: <https:// boris.unibe.ch/69439/1/lohngerecht.pdf $>$ [accessed 21 August 2018].

Jann, B. (2008). The Blinder-Oaxaca decomposition for linear regression models. The Stata Journal, 8, 453-479.

20 Jasso, G. and Webster, M. Jr. (1997). Double standards in just earnings for male and female workers. Social Psychology Quarterly, 60, 66-78.

Korber, M. (2019). The Labour Market Returns to Vocational Education over the Life Course. PhD-Dissertation, University of Lausanne, Lausanne.

Lalive, R. and Stutzer, A. (2010). Approval of equal rights and gender differences in well-being. Journal of Population Economics, 23, 933-962.

Lempen, K. and Voloder A. (2017). Analyse der kantonalen

30 Rechtssprechung nach dem Bundesgesetz über die Gleichstellung von Frau und Mann (2004-2015). Eidgenössisches Büro für Gleichstellung von Frau und Mann EBG, available from: <www. ebg.admin.ch $>$ [accessed 21 August 2018].

Mandel, H. and Semyonov, M. (2006). A welfare state paradox: state interventions and women's employment opportunities in 22 countries. American Journal of Sociology, 111, 1910-1949.

Manning, A. and Swaffield, J. (2008). The gender gap in early-career wage growth. Economic Journal, 118, 983-1024.

Marini, M. M. and Fan, P. L. (1997). The gender gap in earnings at career entry. American Sociological Review, 62, 588-604.

Mazei, J. et al. (2015). A meta-analysis on gender differences in negotiation outcomes and their moderators. Psychological Bulletin, 141, 85.

45 Meier, P. (1986). Damned liars and expert witnesses. Journal of the American Statistical Association, 81, 269-276.

Murphy, E. and Oesch, D. (2016). The feminization of occupations and change in wages: a panel analysis of Britain, Germany, and Switzerland. Social Forces, 94, 1221-1255.

50 Murphy, E. and Oesch, D. (2018). Is employment polarisation inevitable? Occupational change in Ireland and Switzerland, 1970-2010. Work, Employment and Society, 32, 1099-1117.

Napari, S. (2009). Gender differences in early-career wage growth. Labour Economics, 16, 140-148.
Oaxaca, R. (1973). Male-female wage differentials in urban labor markets. International Economic Review, 14, 693-709.

Ochsenfeld, F. (2014). Why do women's fields of study pay less? A test of evaluation, human capital, and gender role theory. European Sociological Review, 30, 536-548.

OECD (2012) Closing the Gender Gap. Paris: OECD.

Oesch, D., McDonald, P. and Lipps, O. (2017). The wage penalty for motherhood: evidence on discrimination from panel data and a survey experiment for Switzerland. Demographic Research, 37, 1793-1824.

Pager, D. (2016). Are firms that discriminate more likely to go out of business? Sociological Science, 3, 849-159.

Pager, D. and Shepherd, H. (2008). The sociology of discrimination: racial discrimination in employment, housing, credit, and consumer markets. Annual Review of Sociology, 34, 181-209.

Polachek, S. W. (2006) How the life-cycle human capital model explains why the gender wage gap narrowed. In Blau, F. D., Brinton, M. C. and Grusky, D. B. (Eds.), The Declining Significance of Gender? New York: Russell Sage Foundation, pp. 102-124 [quote based on: Polachek, S. W. (2004): How the Human Capital Model Explains Why the Gender Wage Gap Narrowed. IZA Discussion Paper 1102, Institute for the Study of Labor, Bonn.]

Polavieja, J. (2008). The effect of occupational sex-composition on earnings: job-specialization, sex-role attitudes and the division of domestic labour in Spain. European Sociological Review, 24, 199-213.

Polavieja, J. and Platt, L. (2014). Nurse or mechanic? The role of parental socialization and children's personality in the formation of sex-typed occupational aspirations. Social Forces, 93, 31-61.

Tomaskovic-Devey, D. and Skaggs, S. (1999). An establishment-level test of the statistical discrimination hypothesis. Work and Occupations, 26, 422-445.

Watermann, R. (2000) Berufliche Wertorientierungen im Wandel. Eine Kohortenanalyse Zur Dynamik Arbeitsbezogener Einstellungen Anhand Von ALLBUS-Umfragedaten. Münster: Institut für sozialwissenschaftliche Forschung e.V.

Benita Combet is a SNF fellowship holder and works at the Ludwig-Maximilians-University in Munich. Her research focuses on identifying the mechanisms behind educational inequality and gender inequality in the labour market. Her earlier work has been published in the European Sociological Review and the Swiss Journal of Sociology.

Daniel Oesch is Professor of economic sociology at the University of Lausanne. His research interests comprise social stratification, labour markets and class voting. $\mathrm{He}$ is the author of the two books Occupational Change in 105 Europe (Oxford University Press 2013) and Redrawing the Class Map (Palgrave Macmillan 2006). 


\section{Appendix}

Table A1. Robustness checks for model 4, Table 1. Dependent variable: (log) monthly earnings

\begin{tabular}{|c|c|c|c|c|c|c|c|}
\hline & (1) & (2) & (3) & $(4)$ & $(5)$ & (6) & (7) \\
\hline & Full model & Full model & Full model & Full model & Full model & Full model & Full model \\
\hline Female & $\begin{array}{c}-0.036^{*} \\
(0.015)\end{array}$ & $\begin{array}{c}-0.038 * \\
(0.015)\end{array}$ & $\begin{array}{c}-0.043 * * \\
(0.014)\end{array}$ & $\begin{array}{c}-0.038 * * \\
(0.014)\end{array}$ & $\begin{array}{l}-0.027 \\
(0.015)\end{array}$ & $\begin{array}{c}-0.064 * * * \\
(0.014)\end{array}$ & $\begin{array}{l}-0.035 \\
(0.018)\end{array}$ \\
\hline Experience in months & $\begin{array}{c}0.032 * * * \\
(0.003)\end{array}$ & $\begin{array}{c}0.035 \% * \\
(0.003)\end{array}$ & $\begin{array}{c}0.030 * * * \\
(0.003)\end{array}$ & $\begin{array}{c}0.032 * * * \\
(0.003)\end{array}$ & $\begin{array}{c}0.034 * * * \\
(0.003)\end{array}$ & $\begin{array}{l}0.033 * * * \\
(0.002)\end{array}$ & $\begin{array}{c}0.036 * * * \\
(0.003)\end{array}$ \\
\hline Female $\times$ Experience & $\begin{array}{c}0.005 \\
(0.004)\end{array}$ & $\begin{array}{c}0.003 \\
(0.004)\end{array}$ & $\begin{array}{l}0.007 * \\
(0.003)\end{array}$ & $\begin{array}{c}0.004 \\
(0.003)\end{array}$ & $\begin{array}{c}0.000 \\
(0.004)\end{array}$ & $\begin{array}{c}0.006 \\
(0.003)\end{array}$ & $\begin{array}{c}0.003 \\
(0.004)\end{array}$ \\
\hline Constant & $\begin{array}{c}8.510 * * * \\
(0.145)\end{array}$ & $\begin{array}{c}8.499 * * * \\
(0.147)\end{array}$ & $\begin{array}{c}8.272 * * * \\
(0.107)\end{array}$ & $\begin{array}{c}8.340 * * * \\
(0.109)\end{array}$ & $\begin{array}{c}8.378 * * * \\
(0.107)\end{array}$ & $\begin{array}{c}8.252 * * * \\
(0.131)\end{array}$ & $\begin{array}{c}8.521 * * * \\
(0.132)\end{array}$ \\
\hline $\begin{array}{c}N_{\text {observations }} / \\
N_{\text {individuals }}\end{array}$ & $3,524 / 1,781$ & $3,178 / 1,613$ & $3,465 / 1,758$ & $3,438 / 1,743$ & $3,524 / 1,781$ & $3,524 / 1,781$ & $3,524 / 1,781$ \\
\hline Sampling weights & Yes & Yes & Yes & Yes & No & Yes & Yes \\
\hline $\begin{array}{l}\text { Matching on } \\
\text { characteristics of : }\end{array}$ & Women & Women & Women & Women & Women & Men & Women \\
\hline Model & RE & RE & RE & $\mathrm{RE}$ & $\mathrm{RE}$ & $\mathrm{RE}$ & Bootstrapping \\
\hline $\begin{array}{l}\text { Exclusion of } \\
\text { observations }\end{array}$ & No & $\begin{array}{r}\text { Influential } \\
\text { weights }\end{array}$ & $\begin{array}{l}\text { Outliers } \\
\text { in salary }\end{array}$ & $\begin{array}{l}\text { Influential } \\
\text { observations }\end{array}$ & No & No & No \\
\hline
\end{tabular}

Standard errors in parentheses: ${ }^{*} P<0.05, * * P<0.01, * * * P<0.001$.

See Table 1 for information on the models.

Model 2: Weights above 30 or below 0.03 were excluded.

Model 3: Wages above or below 1.5 times interquartile difference were excluded.

Model 4: Observations with a student residual below -3 or above +3 were excluded.

Model 5: Coefficient female: $P=0.071$.

Model 7: Bootstrapping (1,000 replications) of matching procedure and RE model, coefficient female: $P=0.051$.

Table A2. The effect of work experience on (log) monthly earnings for men and women (fixed-effects coefficients with matching)

\begin{tabular}{|c|c|c|c|c|c|}
\hline & $\begin{array}{l}\text { Baseline } \\
\text { model }\end{array}$ & $\begin{array}{l}\text { Channel 1: } \\
\text { Initial potential }\end{array}$ & $\begin{array}{l}\text { Channel 2: } \\
\text { Labour market }\end{array}$ & $\begin{array}{l}\text { Channel 3: Parenthood } \\
\text { anticipation }\end{array}$ & Final model \\
\hline Model & 0.2 & 1.4 & 2.3 & 3.1 & 4 \\
\hline Matched on & - & All & All & All & All \\
\hline Independent variables & - & - & All labour market variables & Marriage & All \\
\hline Experience in years & $\begin{array}{l}0.053 * * * \\
(0.002)\end{array}$ & $\begin{array}{l}0.055 * * * \\
(0.005)\end{array}$ & $\begin{array}{c}0.036 * * * \\
(0.005)\end{array}$ & $\begin{array}{c}0.061 * * * \\
(0.006)\end{array}$ & $\begin{array}{c}0.040 * * * \\
(0.005)\end{array}$ \\
\hline Female $\mathrm{x}$ Experience & $\begin{array}{l}-0.003 \\
(0.003)\end{array}$ & $\begin{array}{c}0.001 \\
(0.006)\end{array}$ & $\begin{array}{c}0.004 \\
(0.005)\end{array}$ & $\begin{array}{l}-0.004 \\
(0.006)\end{array}$ & $\begin{array}{c}0.001 \\
(0.005)\end{array}$ \\
\hline Constant & $\begin{array}{c}8.282 * * * \\
(0.005)\end{array}$ & $\begin{array}{l}8.234 * * * \\
(0.011)\end{array}$ & $\begin{array}{c}20.68 \\
(13917071)\end{array}$ & $\begin{array}{c}8.229 * * * \\
(0.010)\end{array}$ & $\begin{array}{c}20.66 \\
(14684144)\end{array}$ \\
\hline
\end{tabular}

Standard error in parentheses, ${ }^{+} P<0.1,{ }^{*} P<0.05, * P<0.01, * * P<0.001$.

$N_{\text {individuals }}=1,781, N_{\text {observations }}=3,524$.

See Table 1 for information on the models.

All time-varying independent variables are interacted with gender. 